\title{
New $\alpha$-amylase and trypsin inhibitors among the CM-proteins of barley (Hordeum vulgare)
}

\author{
Domingo Barber a, Rosa Sanchez-Monge ${ }^{b}$, Enrique Mendez a, Ana Lazaro ${ }^{\text {, }}$ \\ Francisco Garcia-Olmedo ${ }^{b}$ and Gabriel Salcedo ${ }^{\text {b.* }}$. \\ "Servicio de Endocrinologia, Centro Ramón y Cajal, 28034 Madrid, and Departamento de Bioquimica, E.T.S. Ingenieros \\ Agrónomos. Universidad Politécnica. Ciudad Universitaria. 28040 Madrid (Spain)
}

Key words: $\alpha$-Amylase inhibitor: Trypsin inhibitor: Amino acid sequence; (Barley endosperm)

Barley CM-proteins are a group of at least five salt-soluble components (CMa-e) that can be selectively extracted from endosperm with chloroform/methanol mixtures. $N$-terminal sequences of proteins $\mathrm{CMa}$, $\mathrm{CMb}$ and $\mathrm{CMc}$ have been determined and found to be homologous to those previously determined for CMd and $\mathrm{CMe}$, an observation which confirms that their structural genes are members of a dispersed multi-gene family. The purified CM-proteins were tested against trypsin and against $\alpha$-amylases from saliva, pancreas, Aspergillus oryzae, Tenebrio molitor and barley. Besides $\mathrm{CMe}$, which was known to be a trypsin inhibitor, CMc also showed antitrypsin activity, whereas CMa was specifically active against the $\alpha$-amylase from $T$. molitor and no inhibitory activity was found for proteins CMb and CMd. The evolutionary implications of these findings are discussed.

We have described a group of five major components (CMa-e) from the salt-soluble protein fraction of barley endosperm which can be selectively extracted with chloroform/methanol mixtures [1-5]. Based on the similarity of their amino acid compositions and their weak immunochemical cross-reactivity, it has been suggested that the $\mathrm{CM}$-proteins are a homologous family $[3,6]$. The determination of the N-terminal amino acid sequences of some of them has further supported this idea [7]. Furthermore, protein $\mathrm{CMe}$ has been found to be identical with a known trypsin inhibitor [5] and homologous to cereal $\alpha$-amylase inhibitors $[7,8]$. Recently, weak homology has been found between these proteins and cereal storage proteins, such as $\gamma$-secalins and $\alpha$-gliadins [9]. Genes for CM-proteins have been located in chromosomes 1 , 3 and 4 of barley through the analysis of wheat/barley chromosome addition lines [10]. In the present study, we have completed the characterization of the N-terminal amino acid sequences of this group and have tested the inhibitory properties of the purified proteins. A new $\alpha$-amylase inhibitor and an additional trypsin inhibitor have been thus identified.

Insect $\alpha$-amylase was prepared from larvae of Tenebrio molitor, which were the kind gift of $\mathrm{P}$. del Estal, and salivary $\alpha$-amylase was obtained from human saliva. Trypsin and pancreatic, Aspergillus oryzae and barley $\alpha$-amylases used in the inhibition tests were from Sigma.

Extraction and purification of proteins CMa-e was carried out from barley (Hordeum vulgare cv. Bomi) essentially as described [3-5].

Purified proteins were tested for trypsin inhibitory activity following the procedure of Erlanger et al. [11] as modified by Boisen and Djurtoft [12]. Inhibition of $\alpha$-amylases was tested by the method 
of Benfeld [13], in a $0.02 \mathrm{M}$ sodium acetate $/ 0.1 \mathrm{M}$ $\mathrm{NaCl}(\mathrm{pH} 5.4)$ buffer for $T$. molitor $\alpha$-amylase and in a $0.02 \mathrm{M}$ potassium phosphate/ $0.067 \mathrm{NaCl}$ (pH 7.6) buffer for $A$. oryzae, pancreatic and barley $\alpha$-amylases.

Amino acid analysis and sequencing by automatic Edman degradation were performed essentially as previously reported [5].

Chloroform/methanol mixtures selectively extract five major proteins (CMa-e) of the $0.5 \mathrm{M}$ $\mathrm{NaCl}$ fraction from barley endosperm [1.10]. Previous evidence has indicated a close structural relationship among these proteins [4-6]. Direct evidence of the proposed homology was obtained by sequencing the $\mathrm{N}$-terminal amino acids of proteins $\mathrm{CMa}, \mathrm{CMb}$ and $\mathrm{CMc}$ from Bomi barley. There was no evidence of heterogeneity in any of the sequenced residues. The sequences obtained are presented, together with those previously published for proteins CMd and CMe [5,7], in Fig. 1. Protein $\mathrm{CMc}$ from Bomi was found to be identical with protein CM56 from Risø 56 [7]. No homology was found among the $\mathrm{N}$-terminal sequences preceding the first cysteine which varied in length from four to six amino acids, whereas extensive homology could be found in the following stretch of 24 positions, up to the third cysteine. The degree of homology for this part of the sequence in all possible binary comparisons is shown in Fig. 2, together with the compositional divergence indexes, which are based on the amino acid compositions of the whole proteins $[6,14]$.

Proteins CMa-d were tested against trypsin, using $\mathrm{CMe}$, which had been previously identified as a trypsin inhibitor [5], and the soybean trypsin inhibitor as positive controls. Protein $\mathrm{CMc}$ was

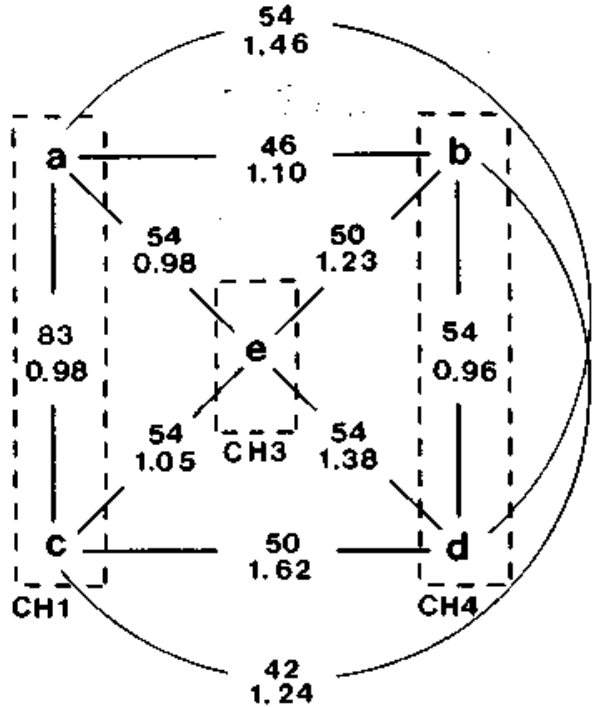

Fig. 2. Binary comparisons of barley proteins $\mathrm{CMa}-\mathrm{e}$. In each case, the upper figure indicates percent homology in the stretch of 24 positions between the first and the third N-terminal cysteine and the lower figure is the compositional divergence index (RCD) of Cornish-Bowden [14] as modified in Ref. 6 (RCD $<1$ indicates homology with $95 \%$ confidence; when $1<$ RCD $<2.2$, there is homology in $90 \%$ of the cases). The amino acid compositions of proteins $\mathrm{CMa}-\mathrm{d}$ are taken from Ref. 3 and that of $\mathrm{CMe}$ has been deduced from the complete sequence in Ref. 20. The discontinuous line $(--\infty)$ indicates chromosomes 1 ( $\mathrm{CH} 1), 3(\mathrm{CH} 3)$ and $4(\mathrm{CH} 4)$.

thus identified as a new inhibitor with about one third of the activity of CMe (Table $\mathbf{l}$ ).

All five purified proteins were tested against $\alpha$-amylases from mammals (pancreatic and salivary), insects ( $T$. molitor) and fungi ( $A$. oryzae), as well as against an edogenous $\alpha$-amylase. Protein CMa was found to inhibit the insect $\alpha$-amylase specifically, with about one-third the activity of the wheat inhibitor used as control (Table II). To

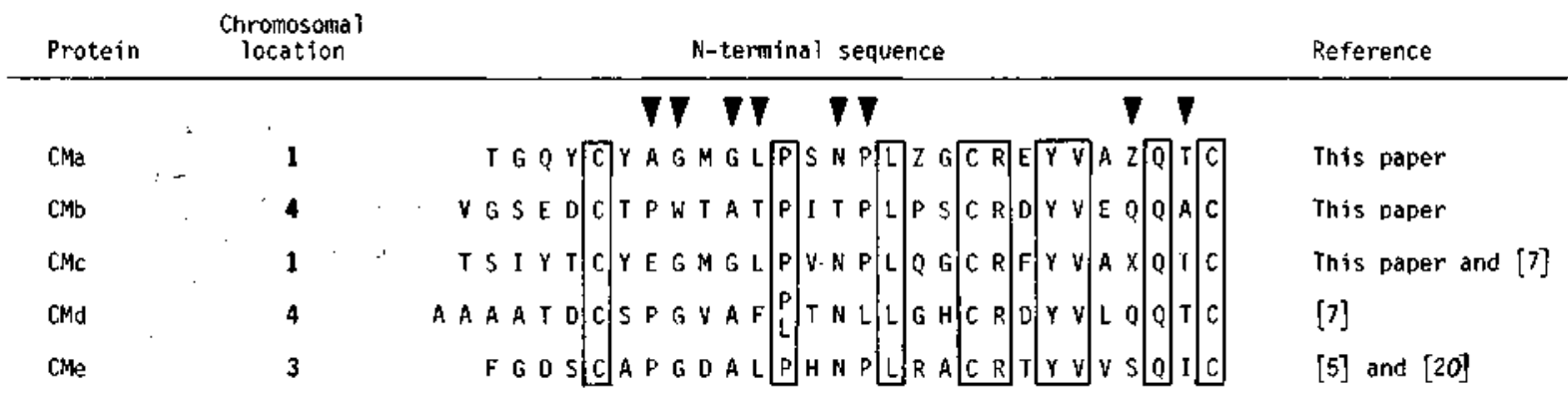

Fig. 1. N-terminal amino acid sequences of barley proteins CMa-e. Invariant positions are boxed. Arrows ( $\nabla)$ indicate positions with a predominant amino acid. The standard IVPAC.IVB single-letter designations are used [22]. 


\section{TABLE I}

\section{INHIBITION OF TRYPSIN BY CMC PROTEIN}

The tests were carried out by a modification [12] of the procedure of Erlanger et al. [11].

\begin{tabular}{lrlr}
\hline Protein tested & $\mu \mathrm{g}$ & $A(410 \mathrm{~nm})$ & \% inhibition \\
\hline- & - & 0.11 & - \\
Bovine serum albumin & 10 & 0.12 & - \\
Soybean trypsin inhibitor & 1 & 0.01 & 91 \\
& 5 & 0.00 & 100 \\
CMa & 10 & 0.12 & 0 \\
CMb & 10 & 0.13 & 0 \\
CMc & 5 & 0.08 & 27 \\
& 10 & 0.06 & 45 \\
CMd & 20 & 0.03 & 72 \\
CMe & 10 & 0.13 & 0 \\
& 5 & 0.01 & $9 l$ \\
& 10 & 0.00 & 100 \\
\hline
\end{tabular}

our knowledge, this is the first inhibitor of heterologous $\alpha$-amylases to be described in barley. None of the other proteins showed inhibitory activity against the $\alpha$-amylases tested.

The sequence data presented here clearly shows that this group of proteins is a true homologous family: in the 24 positions from the first to the third $\mathrm{N}$-terminal cysteine, nine are invariant and at eight others there is a predominant amino acid. Furthermore, the newly sequenced proteins are

\section{TABLE II}

INHIBITION OF $\alpha$-AMYLASE FROM $T$, MOLITOR BY CMa PROTEIN

The tests were carried out by the method of Benfeld [13] modified as described in Materials and Methods. None of the barley $C M$ proteins $(10 \mu \mathrm{g}$ /assay) was active against $\alpha$-amylases from salive, pancreas, $A$. oryzae of barley. A wheat inhibitor of the 0.28 family (see Ref. 21 ) was used as positive control.

\begin{tabular}{lrll}
\hline Protein tested & $\mu \mathrm{g}$ & $A(550 \mathrm{~nm})$ & $\%$ inhibition \\
\hline- & - & 0.49 & - \\
Bovine serum albumin & 10 & 0.48 & 0 \\
Wheat inhibitor (0.28 family) & 1 & 0.08 & 83 \\
& 10 & 0.03 & 94 \\
$\mathrm{CMa}$ & 1 & 0.41 & 16 \\
& 10 & 0.35 & 28 \\
$\mathrm{CMb}$ & 20 & 0.26 & 47 \\
$\mathrm{CMc}$ & 10 & 0.48 & 0 \\
$\mathrm{CMd}$ & 10 & 0.48 & 0 \\
$\mathrm{CMe}$ & 10 & 0.49 & 0 \\
& 10 & 0.48 & 0 \\
\hline
\end{tabular}

also homologous to the $\alpha$-amylase inhibitors of wheat (8-10 positions out of 24 ; Ref. 15), the trypsin inhibitor of corn (10-14 positions out of 24; Ref. 16), the bifunctional inhibitor of ragi (13-14 positions out of 24; Ref. 17) and, to a lesser extent, the $2 \mathrm{~S}$ storage proteins of castor bean and rape $[18,19]$. Although this family had diverged to the extent that different members have different specific inhibitory activity, or even no known activity, their structural divergence is no greater than that found within other groups of proteins with a consistent in vitro activity, such as the $\alpha$-amylase inhibitors of wheat [15]. We have previously shown that these proteins are encoded by a dispersed multi-gene family, whose members are differentially expressed $[5,10]$. Structural relationships merit closer scrutiny vis-à-vis chromosomal locations and inhibitory specificities in an evolutionary context. Thus, it is to be noted that the three proteins with known inhibitory properties share 13 out of 24 positions, but there is a much closer relationship between $\mathrm{CMa}$ and $\mathrm{CMc}$, which respectively inhibit $\alpha$-amylase and trypsin, and whose genes are located in chromosome 1 , than between the two trypsin inhibitors (CMc, $\mathrm{CMe}$ ), whose genes are located in different chromosomes (1 and 3, respectively). Indeed, CMa and $\mathrm{CMc}$ are more closely related than $\mathrm{CMa}$ and any of the known $\alpha$-amylase inhibitors, or CMc and any of the known trypsin inhibitors. Genes for the other two proteins (CMb and CMd) are both located in chromosome 4 and, again, they seem to be more closely related with each other than with any other member of the group, as judged from the values of the compositional divergence index. On the same basis, CMe seems to be closer to the pair $\mathrm{CMa}-\mathrm{CMc}$ than to $\mathrm{CMb}-\mathrm{CMd}$. In summary, our observations indicate that this dispersed multi-gene family has originated by translocation and intrachromosomic duplication and suggest that the duplications are more recent events than the translocations.

We acknowledge the technical assistance of $F$. Soriano and J. Garcia-Guijarro. This work was supported by Comision Asesora de Investigación Científica y Técnica grant No. 2022/83. Scholarships from the Ministerio de Education y Ciencia (A.L.) and the Fondo de Investigaciones Sanitarias (D.B.) are gratefully acknowledged. 


\section{References}

I Salcedo, G., Sanchez-Monge, R., Argamenteria, A. and Aragoncillo, C. (1980) Plant Sci. Lett. 19, 109-119

2 Aragoncillo. C.. Sanchez-Monge, R. and Salcedo, G. (1981) J. Exp. Bol. 32, 1279-1286

3 Salcedo, G., Sanchez-Monge, R. and Aragoncilio, C. (1982) J. Exp. Bol. 33, 1325-1331

4 Paz-Ares, J., Ponz. F., Aragoncillo. C., Hernandez-Lucas, C. Salcedo, G., Carbonero, P. and Garcia-Olmedo. F. (1983) Planta 157, 74-80

5 Lazaro. A., Barber. D., Salcedo, G., Mendez, E. and Garcia-Olmedo. F. (1985) Eur. J. Biochem. 149, 617-623

6 Paz-Ares, J., Hernandez-Lucas. C., Salcedo, G.. Aragoncillo, C., Ponz. F. and Garcia-Olmedo, F. (1983) J. Exp. Bot. 34, 388-395

7 Shewry, P.R., Lafiandra, D., Salcedo, G., Aragoncillo, C., Garcia-Olmedo, F., Lew, E.J.-L.. Dietler, M.D. and Kasarda, D.D. (1984) FEBS Lett. 175, 359-363

8 Odani, S., Koide. T. and Ono. T. (1982) FEBS Lett. 141, 279-282

9 Kreis, M., Forde. B.G., Rahman, S., Miflin. B.J. and Shewry. P.R. (1985) J. Mol. Biol. 183, 499-502

10 Salcedo, G.. Fra-Mon, P., Molina-Cano, J.L., Aragoncillo,
C. and García-Olmedo, F. (1984) Theor. Appl. Genet. 68, 53-59

11 Erlanger, B.J. Kokowsky, N. and Cohen, W. (1961) Arch. Biochem. Biophys. 95, 271-278

12 Boisen, S. and Djurtoft. R. (1981) Cereal Chem. 58. 194- 198

13 Benfeld, P. (1955) Methods Enzymol. 1, 149-158

14 Cornish-Bowden, A. (1980) Anal. Biochem. 105, 233-238

15 Maeda, K., Kakabayashi, S. and Matsubara, H. (1985) Biochim. Biophys. Acta 828, 213-221

16 Mahoney. W.C., Hermodson, M.A., Jones, B., Powers. D.D., Corfman, R.S. and Reeck, G.R. (1984) J. Biol. Chem. 259, $8412-8416$

17 Campos, F.A.P. and Richardson, M. (1984) FEBS Lell. 167. 221-225

18 Sharief, F.S. and Li. S.S.-L. (1982) J. Biol. Chem. 257. 14753-14759

19 Crouch, M., Tenbarge, K.M., Simon, A.E. and Ferl, R. (1983) J. Mol. Appl. Genet. 2, 273-283

20 Odani. S.. Koide. T. and Ono. T. (1983) J. Biol. Chem. 258. 7998-8003

21 Buonocore, V., Petrucci. T. and Silano, V. (1977) Phytochemistry $16,811-820$

22 IVPAC-IVB JCBN (1984) Eur J. Biochem. 138, 9-37 